\title{
Begrepet kunstnerisk kvalitet i den norske kulturskolens rammeplan «Mangfold og fordypning», utfordret med et sideblikk til finsk «grundundervisning i konst»
}

\author{
Anna-Lena Østern ${ }^{\star}$, \\ NTNU, Trondheim, Norge
}

\begin{abstract}
Sammendrag
Hensikten med denne artikkelen er å bidra til økt kunnskap om hvordan «kunstnerisk kvalitet» beskrives og forstås i Norsk kulturskoleråds «Rammeplan for kulturskolen - Mangfold og fordypning» fra 2016. Gjennom en sammenstilling av den norske rammeplanen og skisser til finsk rammeplan for «grundundervisning i konst» når det gjelder verdigrunn, mål og læringssyn undersøkes hva formuleringene løfter frem. Analysen av dokumentene gjennomføres som en kritisk diskursanalyse. Som en forståelsesramme leses begrepet kunst i lys av Bourdieu og i lys av Ranciére, mens begrepet kvalitet leses i lys av ulike kvalitetsforståelser i samtiden med noen konkluderende forslag om alternative begreper som meningsskaping og tolkningsfellesskap. Analysens viktigste funn er at begrepet «kunstnerisk kvalitet» er vanskelig å definere i den norske rammeplanen, og begrepet brukes ikke i de finske rammeplanskissene. De store linjene $\mathrm{i}$ formuleringer om verdigrunn sammenfaller i begge landenes planer. Utfordringen som kan leses ut av de finske skissene er hvordan blikket på samtiden og fremtiden avspeiles i formuleringene $\mathrm{i}$ hva som ses som betydningsfullt og verdifullt i lys av estetiske, etiske og økologiske vurderinger.
\end{abstract}

Nøkkelord: Rammeplan; norsk kulturskole; kunstnerisk kvalitet; kritisk diskursanalyse; undervisning; laring $i$ kunstfag

\begin{abstract}
The aim of this article is to contribute to increased knowledge about how "artistic quality» is described and understood in the Norwegian framework curriculum for music and performing art schools, «Cultural diversity and deeper understanding», from 2016. This is effected through a juxtaposition of the Norwegian framework with sketches of a Finnish framework for basic arts education concerning value foundation, aims and view on learning. The document analysis is carried out as a critical discourse analysis. As a frame of understanding the concept art is read in the light of Bourdieu and Ranciére, while the concept quality is read in the light of different contemporary quality understandings, with some concluding suggestions regarding alternative
\end{abstract}

^Korrespondanse: Anna-Lena Østern, NTNU, Institutt for lærerutdanning, 7491 Trondheim, Email: anna.1.ostern@plu.ntnu.no 
concepts like meaning making and interpretive community. The main finding in the analysis is that the concept «artistic quality» is difficult to define in the Norwegian framework, and that the concept not is in use in the Finnish framework sketch. The main lines in formulations about value foundation coincide in the plans from both countries. The challenge from the Finnish sketches is in this study how the view of present and future times is mirrored in formulations about what is meaningful and valuable in the light of aesthetic, ethical and ecological considerations.

Keywords: Curriculum framework; music and performing arts school in Norway; artistic quality; critical discourse analysis; arts education

Received: November 2016; Accepted: December 2016; Published: January 2017

\section{Innledning}

Hensikten med denne artikkelen er å bidra til økt forståelse for hvordan «kunstnerisk kvalitet» beskrives og forstås i Norsk kulturskoleråds «Rammeplan for kulturskolen Mangfold og fordypning» fra 2016. Artikkelen fanger en avgrenset tidsperiode, nemlig 2015-2016, da Norsk kulturskoleråd gjennomførte et omfattende arbeid for å fornye og utvikle kulturskolens rammeplan og fagplaner. I studien tar jeg inn et komparativt perspektiv gjennom et sideblikk på tilsvarende generell del i finsk «grundundervisning i konst». Finland er et interessant land å sammenlikne med, først og fremst fordi læreplangrunnlaget for grunnundervisning i kunst har en statusmessig sterkere plassering i utdanningssystemet enn den norske rammeplanen, med Utbildningsstyrelsen som leverandør av «grunder för läroplan». Sterkere plassering betyr at planen er forpliktende for den enkelte utdanningstilbyder og at den skal følges. I Finland er det samme instans som skriver læreplangrunnlaget for grunnskole, videregående skole og grunnundervisning i kunst. Jamført med Norge kan organiseringen dermed se ut til å være mer toppstyrt enn den norske kulturskolen er. I Norge er det kommunene som forholder seg til anbefalinger fra Norsk kulturskoleråd. Rammeplanen og nasjonale fagplaner er forhandlet fram i en mer horisontal prosess med mange medvirkende. En annen viktig forskjell mellom organisering av denne undervisningen i Norge og Finland er at Finland ikke har en egen kulturskoleform, slik Norge har i kulturskolen. I Finland kan allerede eksisterende og ulike skoleformer som vokseninstitutt, folkehøgskole og musikkinstitutt tilby grunnundervisning i kunst. Den norske rammeplanen er ikke et dokument med samme grad av forpliktelse som de finske «Grunderna för läroplan för grundundervisning i konst», som er en forskrift som må følges. Hver kommune i Norge er forpliktet til å ha et kulturskoletilbud, mens i Finland er selve det å tilby grunnundervisning i kunst formulert som et valg: kommunen kan tilby grunnundervisning i kunst. I Finland fins en sammenslutning for grunnundervisningen i kunst, kalt TPO-liitto. TPO er en interesseorganisasjon. I Norge fins 420 kulturskoler (i landets 424 kommuner). I Finland tilbys grunnundervisning i 85\% av de 251 finske kommunene gjennom 325 tilbydere (TPOs informasjon om Finland, fra forbundets hjemmeside). Antallet elever som omfattes av tilbudet er $\mathrm{i}$ begge landene mellom 12 og $15 \%$ av barn og unge i grunnskole (videregående skole 
medregnet i Finland). I begge landene er musikk det dominerende faget med rundt $80 \%$ av elevene. I Norge er det køer til kulturskolens elevplasser. I begge landene er undervisningen finansiert ved stat, kommune og elevavgifter. Begge landene tilbyr et utdanningsløp med tre typer av kursprogram. I Norge heter programmene breddeprogram, kjerneprogram og fordypningsprogram. Navnet på den norske læreplanen, «Mangfold og fordypning», peker mot en ambisjon om å tilby både bredde og dybde.

Jeg kaller sammenlikningen med Finland et sideblikk, fordi sammenlikningen halter på noen viktige punkter, først og fremst fordi gjeldende læreplaner fra Finland er fra 2003 og 2005. Jeg henviser kun kortfattet til dem. Utbildningsstyrelsen i Finland arbeider 2016-2017 med et nytt læreplangrunnlag som skal tas i bruk i 2018. I den pågående reformeringsprosessen fins de første skissene der verdigrunnlag, oppgave og mål, læringssyn og læringsmiljø er formulert (Kauppinen \& Hartikainen, 2016). Disse skissene er det finske materialet i denne artikkelen. Verken læreplangrunnlaget som gjelder i dag, eller skissene til et generelt læreplangrunnlag som ble presentert i april 2016 i Finland, nevner begrepet «kunstnerisk kvalitet». I den norske rammeplanen er «kunstnerisk kvalitet» et sentralt begrep.

Sideblikket til finsk grunnundervisning i kunst (Utbildningsstyrelsen 2003, 2005; Kauppinen \& Hartikainen, 2016) viser hovedsakelig et tolkningsfellesskap, men også noen forskjeller. Metodisk vil jeg gjennomføre en analyse av dokumentene som en diskursanalyse hvor begrepet «kunstnerisk kvalitet» problematiseres gjennom en undersøkelse av verdigrunnlag, (for)mål, og læringssyn i den norske rammeplanen og i skissene til den generelle delen av den tilsvarende finske planen ${ }^{1}$.

Bourdieus (1972, 1979) kultursosiologiske begreper felt, habitus og kapital kombinert med Rancières (2012a, 2012b, 2013) problematisering av hva som kan kvalifiseres som kunst, brukes som teoretisk referanseramme i artikkelen. Begrepet kvalitet problematiseres også med utgangspunkt i Moss' (2016) artikkel «Why can’t we get beyond quality?», samt med utgangspunkt i Eliassen og Prytz' (2016) antologi om kvalitetsforståelser i samtidens kunst og kultur.

\section{En kultursosiologisk og kunstfilosofisk referanseramme gjennom Bourdieu og Ranciére}

Kultursosiologen Bourdieu (1972, 1979) har introdusert noen analytiske begreper som har betydning for drøfting av hva som innenfor en gitt kontekst kalles kunst og hva som anses ha kunstnerisk kvalitet, nemlig felt, habitus og kapital. Hans beskrivelse av hvem som definerer grensene for et felt, hvem som har tilgang til det kulturelle feltet og hvem som utestenges, har hatt og har stor betydning for en demokratisering av forståelsen av kunstbegrepet. Han har også pekt på ulike verdier som sosial, økonomisk og kulturell kapital som krefter som virker inn på et gitt felt (Bourdieu, 1979), Begrepet habitus henspiller på de disposisjoner som kvalifiserer for tilhørighet til en bestemt kulturell og sosial gruppe. Habitus er kroppsliggjort atferd som omfatter smak, sosial

\footnotetext{
${ }^{1}$ Heretter kaller jeg den finske «Grunder för läroplanen för grundundervisning i konst» finsk rammeplan.
} 
kompetanse og følelser. En persons habitus er viktig for karrieremuligheter i livet. Habitus kan oppfattes som medfødt, men Bourdieu viser at habitus er kulturelt lært (Bourdieu, 1972). Habitus er ikke noe man velger fritt, heller ikke er habitus bestemt av strukturer, men kan sies å være et resultat av samspill mellom strukturer og kulturell læring over tid. Smith og Riley (2009, s. 135) sammenfatter Bourdieus bidrag til kulturteori gjennom å peke på at hans idé om kulturell kapital “/. . / provide[s] exciting insight into the form and structure of culture. / . ./ His work is able to powerfully theorize the relationship between culture and agency." Bourdieu har fra sin posisjon som fransk kultursosiolog bidratt til forståelsen av at kunst ikke er et entydig begrep, og at det er knyttet til makt både sosialt og økonomisk.

En annen fransk filosof, Ranciére, har utformet en filosofisk tenkning omkring hvordan kunst knyttes til det sanselige og det politiske. I boken Sanselighetens politikk (2012b) beskriver Rancière tre ulike regimer for kunst. Et regime forklares som de måter som kunst defineres på og som dermed angir hva som kan kalles kunst og hva som ikke kan kalles kunst innenfor et bestemt regime. Han er opptatt av hvordan kunst forholder seg til verden og hvordan regimets tenkning giør at noe blir anerkjent som kunst. Rancière beskriver tre historiske regimer og knytter hvert regime til en filosof: Det etiske regimet knyttes til Platon. Da vurderes kunst som en nedbrytende eller oppbyggende praksis for individer, grupper eller samfunn. Kunst har i Platons forståelse ikke en egenverdi. Det poetiske regimet knyttes til Aristoteles og mimesistanken om representasjon. Kunst tilkjennes en egenverdi, og innenfor kunstfeltet skapes hierarkier og regler for hva som er kvalitet i kunstuttrykk. Det estetiske regimet tar utgangspunkt i Schiller og tysk romantikk. Maurseth (2015, s. 177) skriver: «Det vesentlige i det estetiske kunstregimet er at kunsten blir vurdert ut fra hvordan den appellerer til våre sanser, og ut fra hvordan den tilveiebringer nye måter å se, høre, sanse, fornemme og tenke på.» Rancières begrep det estetiske regimet knytter det sanselige, opplevelsen, følelser og tenkning sammen i en beskrivelse av en demokratisk kunstforståelse og en forståelse av politikk. Denne kunstforståelsen er grunnleggende inkluderende. Han mener ikke at kunsten er politisk gjennom å ha et tydelig politisk innhold, men gjennom å forme sansbart materiale til noe som utfordrer menneskers forståelse. Den stadige forskyvningen i forståelse av hva som kan kalles kunst, utfordrer etablerte sannheter og forestillinger. Rancière beskriver i Den emansiperte tilskuer dissens, uenighet, som produktiv og mener at når etablerte sannheter og forestillinger utfordres, skapes nye muligheter for å sanse, tenke og handle (Rancière, 2012a, s. 76). Jeg skrev at disse regimene er beskrevet ut fra et historisk perspektiv, men det er ikke vanskelig å se at alle disse tre regimene fortsatt kan spores i vurderinger av hva som kan kalles kunst og kunstnerisk.

\section{Fra kvalitet til meningsskaping}

Moss (2016) skriver i artikkelen «Why can't we get beyond quality?» at kvaliteten er et valg, ikke en nødvendighet. Valget er en følge av en spesiell posisjonering som har skrevet seg inn i verdier og antakelser. Dermed må arbeid med kvalitet kontekstualiseres. Moss konstaterer at man med en spesifikk definisjon av kvalitet prøver å skape en atferd $\ll / \ldots /$ in the hope of producing certain desired effects and averting 
certain undesired events. It is a technology of normalisation, establishing norms against which performance should be assessed, thereby shaping policy and practice» (s. 10). Moss skriver om småbarnspedagogikk, ikke om kunst og kunstinstitusjoner, men hans resonnement kan være av interesse også for drøftingen av kvalitet $\mathrm{i}$ kunstkontekst. Han foreslår et annet begrep som alternativ til kvalitet, nemlig meningsskaping. Begrepet meningsskaping knytter Moss (med et lån fra Dahlberg) til verdivurdering på følgende måte:

Meaning making is 'evaluation as a democratic process of interpretation, a process that involves making practice visible and thus subject to reflection, dialogue and argumentation, leading to a judgement of value, contextualized and provisional because it is always subject to contestation' (Dahlberg et al, 2013, ix). It values subjectivity, uncertainty, provisionality, contextuality, dialogue and democracy. (Moss, 2015, s. 11)

Moss konkluderer i artikkelen med å si at ønsket om å komme fram til en entydig og rask løsning når det gjelder kvalitetsutdanning, er først og fremst politisk og etisk praksis.

Antologien Kvalitetsforståelser. Kvalitetsbegrepet $i$ samtidens kunst og kultur (Eliassen \& Prytz, 2016) er utgitt av Norsk kulturråd. Den utgiør et bidrag til analysen av hvordan kvalitet forstås innenfor ulike kunstkontekster. Eliassen (2016, s. 21f.) skriver i innledningen at forvaltningen av kvalitetsbegrepet påvirkes av hvilke rammer vurderingen foregår innenfor. Han problematiserer også om det alltid er meningsfullt å se på kvalitet som den rette målestokken i vurdering. Å måle kvalitet betyr et skifte fra de kunstneriske og kulturelle aktivitetene til de produkter som disse genererer. Eliassen $(2016$, s.15) konstaterer at verdihierarkier ligger til grunn for forskjellige begreper om kvalitet.

I drøftinger av begrepet kvalitet i antologien beskrives kontekst som et flerstemt erfaringsrom. Lindsköld (2016, s. 163) spør hva slags rasjonalitet som styrer vurderinger av kvalitet. Hun foreslår en teleologisk, målrettet rasjonalitet og en instrumentell nytterasjonalitet. Hun konstaterer videre at sosiale, politiske og kulturelle vurderinger reproduseres gjennom kulturpolitikken. Lindsköld (2016, s. 165) skriver også at kvalitet kan beskrives som et begrep som er tomt for mening. Det fylles med innhold av ulike subjektposisjoner som kjemper om hegemoni i en diskurs. Hun hevder at kvalitet aldri kan være upolitisk. Begrepet er politisk ladet. Oterholm (2016, s. 146) tar i en artikkel i antologien for eksempel tak i kulturpolitiske verdier knyttet til bibliotekenes samfunnsmandat gjennom en analyse av bibliotekarblogger fra Lom bibliotek om hvordan bibliotekarene møter lesernes smakspreferanser i valg av litteratur: «Det er de emosjonelle, kroppslige og kunnskapsutvidende kvalitetene som er viktige, sammen med det i litteraturen som giør deg aktiv og deltakende.»

Også i rammeplanen for kulturskolen, "Mangfold og fordypning», kan ulike diskursive krefter identifiseres. Forfatterne i antologien Kvalitetsforståelser løfter fram hvordan ulike begrunnelser kan få tolkningsfortrinn. Det gjelder spørsmål om originalitet og nyskaping i motsetning til tradisjon og sjangerkonvensjoner. Hvis kunstnere etterstreber originalitet og nyskaping, bryter de ofte med innarbeidede 
kvalitetsnormer (Lindsköld, 2016, s. 176-177). I antologien nevner Lindsköld noen begreper som kan stilles mot hverandre: finkultur-populærkultur, bevaringnyskaping og amatør-profesjonell. Hun konstaterer at «Politik är beslut där val måste göras mellan motstridiga, ideologiska alternativ (s. 177).

\section{Tolkningsfellesskap og meningsskaping}

Jeg har skapt en forståelsesramme for analysen gjennom en lesning av begrepene kunst og kvalitet. Man kan si at jeg har beskrevet begrepene slik at de kan brukes som støtte for en kritisk diskursanalyse av begrepet «kunstnerisk kvalitet»i den norske rammeplanen. Jeg retter oppmerksomhet mot hvilke aktører som har «agency», og som dermed kan være aktører innenfor det feltet som kulturskolen i Norge representerer.

Basert på analysen av kvalitetsbegrepet er en mulig konklusjon at kvalitet er et ladet begrep som trenger kontekstualisering for å gi mening. Litteraturpedagogen Fish (1978) knyttes til begrepet «interpretive communities» i forbindelse med tolkning av litterær fiksjon. Begrepet tolkningsfellesskaper kan imidlertid være anvendbart også i andre sammenhenger der man gjør skjønnsmessige vurderinger og hvor man trenger å forhandle seg fram til vurderingskriterier. Meyer (2010) viser i Visuell makt. Bilder, blikk og betrakter at det handler om å sette grenser og markere forskjeller, og om hvem som skal få utfolde seg som subjekt:

Å SE, Å BLI SETT, Å SE SEG SELV. Det handler om å sette grenser og markere forskjeller i det vi ser og sanser. Men det skjer ikke uten strid. Striden står mellom hvem som skal få utfolde seg som subjekt, og hvem som skal holdes nede av de andres blikk og reduseres til objekt. Kampen om blikket gir både oss og de andre identitet. (Meyer, 2010, s. 164)

En konklusjon på analysen av begrepene kunst og kvalitet er at kunstnere og kunstinstitusjoner forhandler seg fram til hva «kunstnerisk kvalitet» er, og noen interesser har tolkningsfortrinn. Forståelsen av begrepet «kunstnerisk kvalitet» i rammeplanen «Mangfold og fordypning» er forhandlet fram i en omfattende og relativt horisontal prosess, med åpne høringsrunder, med arbeidsgrupper sammensatt av sakkyndige under ledelse av administrasjonen ved Norsk kulturskoleråd, og med en del benchmarking i form av sammenlikning med kulturskoleformene i de andre nordiske landene.

\section{Metode}

På bakgrunn av den teoretiske rammen jeg har tegnet for denne studien, har jeg formulert følgende problemstilling:

Hvordan kan sammenligning av verdigrunnlag, (for)mål og laringssyn $i$ rammeplanen for den norske kulturskolen respektive $i$ det finske lereplangrunnlaget bidra til forståelse av begrepet kunstnerisk kvalitet?

\section{Materiale}

«Rammeplan for kulturskolen - Mangfold og fordypning» (Norges kulturskoleråd, 2016) er i hovedsak analysematerialet i denne studien. Jeg nevner kort det någjeldende læreplangrunnlaget for den finske grunnundervisningen i kunst som et 
sekundært materiale (Utbildningsstyrelsen, 2005, s. 34-41; Utbildningsstyrelsen, 2003, s. 7-18). Disse finske læreplanene er fra samme tid som den første spede begynnelsen til en rammeplan for norsk kulturskole (Norsk kulturskoleråd, 2003), men de finske planene er også da strukturert på samme måte som andre læreplangrunnlag fra den finske Utbildningsstyrelsen. Sideblikket til finsk grunnundervisning i kunst omfatter derfor de første skissene til mål, verdigrunn og syn på læring i den generelle delen av læreplangrunnlaget for grunnundervisning i kunst som er under utvikling i Finland (Kauppinen \& Hartikainen, 2016). Det reformerte læreplangrunnlaget er tenkt å bli gitt ut i 2017 og bli tatt i bruk i 2018 .

\section{Forskerposisjonering}

Forskeren kan ikke ta en rolle utenfor diskursen og iaktta og analysere på avstand. Forskeren er et subjekt blant andre innenfor diskursens ramme. Forskningen bedrives innenfor hva som er mulig ut fra rammene for diskursen, samtidig som forskeren er med på å artikulere hva som er mulig (Bolander \& Fejes, 2010, s. 90114). Som forsker innenfor feltet kulturskole er jeg både innenfor og utenfor feltet. Jeg er innenfor feltet i den betydningen at jeg har kompetanse innenfor faget drama og teater, og litteratur, og og jeg har kunstdidaktisk forskerkompetanse (Østern, Angelo \& Stavik-Karlsen, 2013; Østern, 2014). Jeg har også vært med å på å restarte et kulturskolerelatert forskningsnettverk (http://www.kulturskoleradet.no/), og initiere en kulturskolekonferanse, "Cutting edge kulturskole!» (Østern, T., 2016), der alle fag i kulturskolen potensielt skal gis plass i presentasjoner av forsknings- og utviklingsarbeid. Jeg er også innenfor i den betydningen at jeg har vært aktiv som lærerutdanner både i Finland og Norge. Jeg har for eksempel deltatt i Utbildningsstyrelsens planlegging av gymnasiediplom i teaterkunst og diplom i muntlig färdighet (Østern, 1994; Østern, 1997; Østern, Risan \& Eriksson, 2005). Gjennom min profesjonelle rolle som lærerutdanner og forsker har jeg stor interesse for feltet og for de verdier som disse fagene fremmer hos barn og unge gjennom det verdigrunnlaget, de mål og det læringssynet som formuleres for kulturskolen.

\section{Diskursanalyse}

Diskurser ses som bestemte måter å snakke og forstå på. McMullen (2011, s. 206) konstaterer at det fins en mengde varianter av diskursanalyse, og at de varierer når det gjelder epistemolgisk posisjonering og syn på betydningen av teori. Hun sier at mengden av ulike typer av diskursanalyse har bidratt til at grensene mellom ulike typer av diskursanalyse viskes ut. Det betyr at en forsker kan lage en syntese av flere diskursive tilnærmingsmåter. I denne artikkelen tar jeg utgangspunkt i kritisk diskursanalyse og knytter analysen til Foucaults forståelse av makt. Foucault har synliggiort kampen mellom ulike diskurser og har vist hvordan en diskurs når en hegemonisk posisjon og fester seg (Foucault, 1999). Faircloughs (1995) kritiske diskursanalyse har til hensikt å vise maktens effekter og på den måten streve mot sosialt likeverd. Jeg betrakter dermed de som har produsert rammeplanen som aktive agenter, subjekter som konstruerer sin forståelse av fenomenet kunstnerisk kvalitet i rammeplanen.

Jeg studerer tekstene for å kunne beskrive hvordan de både inneslutter og utelukker. Hvilke sannheter skapes om hva som er kvalitet, og dermed om hva som 
ikke er kvalitet, hva som tas for gitt og hva som usynliggjøres. I Når det gjelder Goodlads (1979) beskrivelse av læreplannivåer kan denne analysen muligens plasseres på nivået den formelle læreplan, eller kanskje heller på nivået ideenes læreplan. Jeg prøver nemlig en lesning av dokumentene for å finne ut mer om hva som i læreplanen beskrives som kunstnerisk kvalitet. Jeg har avgrenset analysen til formuleringer om verdigrunnlag, (for)mål/oppgave, kunnskap/læringssyn og læringsmiljø. Gjennom analysen prøver jeg å fange noen konturer av hvordan kunstnerisk kvalitet skrives fram i den norske rammeplanen, utfordret av formuleringer i de finske skissene til rammeplan.

Et spørsmål i diskursanalyse er hvem som snakker i teksten. I begge tekstene er det arbeidsgrupper tilknyttet planarbeidet som har strukturert og skrevet teksten under ledelse av Norsk kulturskoleråd respektive Utbildningsstyrelsen i Finland. I analysen anser jeg disse som subjekter, også om jeg av hensyn til enkelhet i skrivemåte gjør planene til 'subjekter' i denne framstillingen. Jeg kaller også (for å gjøre teksten mere flytende) de finske skissene 'planer' i den følgende analysen. Jeg har sammenstilt tekstutdrag fra planene i tre matriser som omfatter de tre temaer jeg har valgt å undersøke og stille ved siden av hverandre.

I matrise 1 vises en sammenstilling av formuleringene om verdigrunnlag i planene. Formuleringene viser at verdigrunnlaget når det gjelder de store linjene, har sammenfallende retning i vedrørende menneskesyn og demokratiforståelse.

Matrise 1. Sammenstilling av tekstutdrag om verdigrunnlag.

Verdigrunnlag i norsk kulturskoles rammeplan «Mangfold og fordypning»

(2016, s. 7).

Bygger på humanistisk menneskesyn og på samfunnsverdier som fellesskap, ytringsfrihet, menneskeverd og demokrati.

... alle mennesker har formsans og uttrykksbehov som kan utvikles gjennom opplæring.

Respektere andre kulturer - trygghet i egen identitet.

Videreføre og fornye kulturarv.

Kulturaktiviteter skaper arenaer for tilhørighet og sosialt fellesskap og kan inspirere til deltakelse i det uenighetsfellesskapet som er en forutsetning for et fungerende demokrati.

Kulturskolens hovedanliggende er å utvikle og ivareta kunstnerisk og kulturell kompetanse.
Verdigrunnlag $i$ grundundervisning $i$ konst, finsk rammeplan (Kauppinen \& Hartikainen, skisse 15.4. 2016; forfatterens oversettelse fra finsk).

Bygger på oppfatningen at hvert menneske er unikt og har verdi som individ.

Bygger på menneskerettigheter, likestilling, å behandle alle på en likeverdig måte.

Støtte for å vokse som menneske gjennom å utvikle kunsten å tenke og gjennom å utvikle kreativitet.

Respekt for kulturers mange former.

Støtte utvikling av elevens kulturelle identitet og av ansvarsbevisst medborgerskap.

... bygger på ulik kulturarv og fornyelsen av den med utgangspunkt i kunstartene.

Skape grunnlag for sosial og kulturell holdbar utvikling.

Man innvirker på sitt eget liv gjennom interaksjon med andre og med sine omgivelser.

Utgangspunkt er de måter å produsere kunnskap og vise kunnskaper på som er karakteristiske for kunst.

Spørsmål om estetikk, etikk og økologi styrer vurderingen av hva som er betydningsfullt og verdifullt. 
Begge planene legger vekt på det sosiale fellesskapet, på kulturarv og fornyelse av kulturarv. Begge nevner kulturell identitet. Den norske planen formulerer en tanke om at alle har formsans og uttrykksbehov som kan utvikles gjennom opplæring, mens den finske planen skriver om støtte for å vokse som menneske, lære seg å tenke og være kreativ. Den finske planen nevner i verdigrunnlaget temaer som ansvarsbevisst medborgerskap og sosial og kulturell holdbar utvikling.

Ifølge den norske planen er kulturskolens hovedanliggende å utvikle og ivareta kunstnerisk og kulturell kompetanse. Utsagnet tolker jeg som et innspill til hvordan læreplanen konkretiserer kunstnerisk kvalitet gjennom å nevne kunstnerisk og kulturell kompetanse. Den finske planen knytter vurdering av hva som er betydningsfullt og verdifullt til spørsmål om estetikk, etikk og økologi. Den finske planen er her tydelig når det gjelder forståelse av kvalitet som meningsskaping. Den finske planen tar i verdigrunnlaget utgangspunkt i kunstens måte å produsere kunnskap på og å vise kunnskaper på. Gjennom denne formuleringen peker planen på at kunst produserer kunnskap.

I den norske planen brukes begrepene formål og mål, mens den finske bruker begrepet oppgave (Matrise 2). Begge planene beskriver muligheter til fordypning og langsiktig-het Begge planene bruker ordet kulturell, men den norske i sammensetningen kulturell kompetanse og den finske i sammensetningen kulturell leseferdighet. Begge planene ønsker å bidra til danning eller allmenndanning. I verdigrunnlaget $\mathrm{i}$

Matrise 2. Sammenstilling av tekstutdrag om (for)mål/oppgave.

\begin{tabular}{l} 
Kulturskolens formål og mål i Norge i \\
rammeplanen «Mangfold og fordypning» \\
$(2016$, s. $7-8)$. \\
\hline Kulturskolen skal gi opplæring av høy faglig og \\
pedagogisk kvalitet til alle barn og unge som \\
ønsker det. \\
Formålet med opplæringa er å lære, oppleve, skape og \\
formidle kulturelle og kunstneriske uttrykk.
\end{tabular}

Gi fordypningsmuligheter som kan danne grunnlag for videregående og høyere utdanning innen kunst- og kulturfag.

Gi alle elever mulighet til å utvikle kunnskaper og ferdigheter i kunstfag

Gi alle elever mulighet til å finne og formidle egne kunstog kulturuttrykk.

... medvirke til å styrke kulturell kompetanse.

... bidra til barns og unges danning, fremme respekt for andres kulturelle tilhørighet, bevisstgiøre egen identitet, bli kritisk reflekterende og utvikle egen livskompetanse.
Oppgave og mål for grundundervisning i konst i finsk rammeplan (Kauppinen \& Hartikainen, skisse 15.4.2016, forfatterens oversettelse fra finsk).

Målrettet undervisning som går fra nivå til nivå, rettet i første hånd mot barn og unge. Gi mulighet til langsiktige studier etter eget ønske og egen interesse. Fordype elevens allmenndanning, styrke delaktighet og kulturell leseferdighet.

Utvikle ferdighet å uttrykke seg.

... utvikle elevens multilitterasitet.

Skape forutsetninger for utvikling av kunst og kunstpedagogikk både nasjonalt og internasjonalt.

Bidra til å påvirke sitt livsmiljø og samfunnet med kunstens virkemidler.

Styrke elevens aktive og kreative måte å forholde seg til kunst på. Gi støtte til livslang aktiv utøvelse, til å kunne tolke kunst, til kunstinteresse og livskvalitet. 
den finske planen nevnes å lære seg å tenke og å være kreativ. I formålet i den norske planens nevnes å fremme kritisk refleksjon og å utvikle livskompetanse. I læreplanen for den norske grunnskolen, kalt Kunnskapsløftet (KL 06), vektlegges forskjellige kompetanser. Spor fra KL 06 er synlig mange steder i den norske rammeplanen for kulturskolen. I Finland er et nytt læreplangrunnlag for grunnskolen tatt i bruk fra 2016, og også i formuleringene i de finske planene for grunnundervisning i kunst er grunnskolens læreplangrunnlag synlig i betoningen av økologiske prinsipper om holdbarhet og av hva som er meningsfullt. Multilitterasitet skal etter den finske grunnskolens læreplangrunnlag være et tema i alle fag.

Analysen av målformuleringer i den norske planen gir noen bidrag til tolkning av kunstnerisk kvalitet som høy faglig og pedagogisk kompetanse og kulturell kompetanse. Den finske planen artikulerer holdbarhet som et mål, viser opptatthet av hva kulturell leseferdighet bidrar med, samt ønsker å styrke elevenes multilitterasitet.

I analysen av formuleringene om kunnskap, læringssyn og læringsmiljø brukes i den norske planen begrepet kunstnerisk kvalitet. I den finske planens formuleringer om verdigrunnlag kommer man forbi begrepet kvalitet giennom å skrive om måter å produsere kunnskap og vise kunnskaper på som er karakteristiske for kunst. Også denne formuleringen trenger å avkodes for å gi mening. Den finske planen gir støtte til avkodingen gjennom å skrive at spørsmål om estetikk, etikk og økologi styrer vurderingen av hva som er betydningsfullt og verdifullt.

I den generelle delen av den norske planen fins formuleringer om kunnskap i kulturskolen, mens formuleringer om læringsmål fins under de enkelte fagplanene. Jeg går ikke inn $\mathrm{i}$ analyse av fagplanene $\mathrm{i}$ denne studien. Derfor snakker tekstutdragene i matrise 3 kun delvis 'samme språk'. Formuleringene fra den finske planen omfatter generelle læringsmål og formuleringer om læringsmiljø. Den finske planen tar utgangspunkt i eleven gjennom å skrive at eleven er en aktiv agent (kan også oversettes som en aktivt handlende person). Den norske planen bruker begrepet opplæring og retter dermed oppmerksomhet mot didaktisk innsats. Planen har formuleringer om at lærerens veiledning omfatter å forklare, vise og korrigere. I den norske planen har vurdering for læring fått stor plass.

Kroppslig læring beskrives som sentral i både den norske og den finske planen, men i den norske er formuleringen om kropp og bevissthet nesten dualistisk gjennom beskrivelse av at de står $\mathrm{i}$ et nært forhold til hverandre.

I formuleringene om kunnskap giør forfatterne av den norske planen et forsøk på å konkretisere hvor kunstnerisk kvalitet kan utvikles, nemlig kvalitet på den kunstneriske utførelsen, kvalitet på formidlingen, kvalitet på den enkelte undervisningstimen, kvalitet på produksjonen og kvalitet på elevens egen innsats. Planen inneholder formuleringer om å trene og øve, men også om å besøke profesjonelle kunstinstitusjoner og møte utøvere. Planen konkluderer med: Slik læres normer for kvalitet. I den finske planen er formuleringene mer allmenne, men de peker i samme retning gjennom å uttrykke at læringsmiljøet skaper forutsetninger for å arbeide på den spesifikke måten man gjør innenfor det kunstområdet man studerer aktivt og langsiktig.

Den norske planen hevder at velutstyrte undervisningsrom etc. er forutsetning for undervisning på høyt nivå, mens den finske planen nevner mangesidige læringsmiljøer 
Matrise 3. Sammenstilling av tekstutdrag om kunnskap/læringssyn og læringsmiljø.

Syn på kunnskap $i$ den norske rammeplanen «Mangfold og fordypning»

(2016, s. 27). (Læringsmål finnes i de planene for de enkelte fag.)
Syn på læring og læringsmiljø for grundundervisning $i$ konst $i$ finsk rammeplan (Kauppinen \& Hartikainen, skisse 15.4.2016, forfatterens oversettelse fra finsk).

Eleven er en aktiv agent.

Læring skjer i interaksjon.

Bruk av ulike sanser og kroppslighet er sentrale i læring.

Læring er innenfor alle kunstområder en helhetlig prosess.

annet, kan det ha sterke elementer av menneskekunnskap. Det berører grunnvilkår ved tilværelsen ...

Kulturskolen må forankres tydelig i kunstneriske mål.

Kunstnerisk kvalitet vil kunne defineres ulikt fra kunstfag til kunstfag: kvalitet på den kunstneriske utførelsen, kvalitet på formidlingen, kvalitet på den enkelte undervisningstimen, kvalitet på produksjonen og kvalitet på elevens egen innsats.

Det er viktig å hjelpe elevene til å etablere hensiktsmessige og selvstendige måter å øve eller trene på. (s. 28)

Elevene får veiledende og læringsstøttende tilbakemeldinger underveis i prosessen.

Læreren forklarer, viser, korrigerer.

Vurdering for læring kan ha form som utviklingssamtaler ... der ansvarliggjøring og elevmedvirkning er viktige aspekter. (s. 28)

Et viktig diskusjonstema for lærere og ledere er derfor hvilke forutsetninger som må være til stede i arbeidet mot kunstnerisk kvalitet. Kulturskolens lærere skal ha både pedagogisk kompetanse og et høyt kunstnerisk nivå. I tillegg bør elevene oppleve samarbeid med profesjonelle kunstinstitusjoner og profesjonelle utøvere utenfor kulturskolen. Slik tilegnes normer for kvalitet. (s. 27)

... en forutsetning for å utøve fagene på høyt nivå er knyttet til velutstyrte undervisningsrom og god kvalitet på utstyr, saler, scener, instrumenter og verktøy. (s. 27)
Elevene veiledes til å forstå sine erfaringer og sin læring.

En oppmuntrende og støttende veiledning styrker elevens tiltro til egne muligheter.

[Læringsmiljøet] skaper forutsetninger for å arbeide på den spesifikke måten man gjør innenfor det kunstområdet man studerer aktivt og langsiktig.
Mangesidige læringsmiljøer støtter elevenes vekst og inspirerer dem til å lære.

Gir alle mulighet til erfaringer med å lykkes. Trygge studiemiljø både fysisk, sosialt og psykisk.

som inspirerende for elevens læring. Den finske planen nevner også betydningen av et trygt læringsmiliø fysisk, sosialt og psykisk.

\section{Sammenfatning av de diskursanalytiske bidragene til forståelse av kunstnerisk kvalitet}

Gjennom mikroanalysens mulighet til å studere bruk av retorikk og gjennom å prøve en sammenstilling av formuleringer fra norsk og finsk plan, har jeg kunnet peke ut et 
tolkningsfellesskap når det gjelder de store linjene i verdigrunnlaget. De store linjene knyttet til demokratiforståelse, likeverd og dannelse gir noen grunnleggende føringer for hvordan kunstnerisk kvalitet kan tolkes, men markerer også grenser for tolkning.

Begge planene legger vekt på at programmene i planene gir mulighet for langsiktighet og fordypning gjennom aktivt arbeid innenfor den kunstformen som er valgt. Mens den norske planen er opptatt av høy kompetanse hos lærerne og kunstnerisk kvalitet i alle sammenhenger, unnviker den finske planen bruk av begrepet kvalitet. Den finske planen retter oppmerksomheten mot kunstens måte å skape kunnskap på og å formidle eller vise den. Den fokuserer på eleven som aktiv i læringsprosessen, og lærerens rolle nevnes ikke så hyppig som i den norske rammeplanen.

Begge planene legger vekt på det sosiale fellesskapet og utviklingen av kulturell kompetanse/kulturell leseferdiget. Den kulturelle kompetansen ser ut til å være en del av den kunstneriske kvaliteten knyttet til en person. Den kulturelle leseferdigheten peker mot en multimodal leseferdighet som innebærer å kunne lese både tekst og kontekst.

Den norske planen nevner betydningen av møte med profesjonelle innenfor aktuelle kunstfelt og konkluderer med at slik skapes normer for kvalitet. Med Bourdieus begreper felt, habitus og kulturelt kapital som veiledende kan formuleringen om normer for kvalitet gi føringer til avgrensning av kulturfeltet, til beskrivelse av passende habitus og også til vurdering av hva som er kulturell kapital i sammenhengen. Den finske planen har også innforstått en norm som formuleres som den spesifikke måten man arbeider på innenfor det kunstområdet man studerer aktivt og langsiktig. Det ser ut som om den finske Utbildningsstyrelsen har en bevissthet om vanskene med å definere kvalitet og at den derfor velger andre formuleringer som kan knyttes nærmere til meningsskaping i en spesifikk kontekst.

Analysens viktigste 'funn' er nok at begrepet kunstnerisk kvalitet er vanskelig å definere eksakt, fordi det er knyttet til tolkningsfellesskap og styrt av verdivurderinger som kan føres tilbake til politiske, sosiale og økonomiske vurderinger.

\section{Drøfting av den videre konteksten og tolkningsfellesskapet $i$ norske kulturskoler}

Jeg vil i den avsluttende drøftingen forlate de finske planene og konsentrere drøftingen om den norske konteksten som rammeplanen er tenkt å fungere innenfor. En konkluderende tanke som gjelder den finske planen, er at jeg nok i den kan se sporene av et samfunn som må forholde seg til en stadig strammere økonomi, en tøff konkurranse om jobber og mange utfordringer i knyttet til et stadig mer flerkulturelt samfunn. Grunnundervisningen i kunst rettes både mot de som skal bli profesjonelle kunstutøvere og mot de mange som kan ha kunst som en livslang interesse. En rapport fra den finske regjeringen (Undervisnings- och kulturministeriet, 2011) om kulturens framtid i Finland peker fram mot 2035. I rapporten tegnes et bilde av et kulturintensivt samfunn der kunst har stor betydning gjennom ulike hybridprosjekter med teknologi og kunst, entrepenørskap og kunst og mere. En av konklusjonene i 
rapporten er at kunst- og ferdighetsfagene med dette langtidsperspektivet må styrkes i skole og lærerutdanning.

\section{Den norske rammeplanen «Mangfold og fordypning» som et flaggskip for norsk kulturskole}

Den norske rammeplanens retorikk viser et tydelig ønske om å heve statusen for kulturskolen. Rammeplanen er inspirert av retorikken i KL 06, noe som synes i bruk av begreper som vurdering for læring, læringsmål, læringsutbytte, kompetanser og kvalitetssikring. Rammeplanens ambisjon om å gi støtte til kulturskolenes kompetanseheving synes gjennom bruk av ord som «skal» og «bør». Rammeplanen har en detaljrikdom og konkretiseringsgrad som kan vekke spørsmål om hva som er igjen å skrive om for de lokale fagplangruppene. Rammeplanen har fått inspirasjon fra skriveforskningens skrivehjul og har utformet kreative faghjul som samler sentrale begreper innenfor hvert fag i kulturskolen. Rammeplanen kan overgripende ses som et kunnskapsløft for kulturskolen i Norge. Selv om den er rådgivende, har den potensial til å utvikle kulturskolen som en sentral kulturinstitusjon i Norge.

Rammeplanen nevner behov for kompetanseheving gjennom FoU-prosjekter og forskning om denne skoleformen i Norge. Kunstforståelsen i fagplanene peker i ulike retninger med innslag av Ranciéres tre regimer, men kanskje med vekt på et poetisk regime med noen innslag av et estetisk regime. Her blir hele kulturskolefeltet utfordret til fortsatt å skrive fram en kunstforståelse som er relevant for norsk samtid. Ettersom rammeplanen legger slik vekt på høy kompetanse og kunstnerisk kvalitet, kan Stortingsmelding 28 (Meld. St.ting 28, 2015-2016) og oppfølgingen av Ludvigsenutvalgets utredning «Fremtidens skole» (NOU, 2015) med vekt på dybdelæring brukes for å løfte fram nettopp kunstens måte å skape kunnskap på som utforskende dybdelæring i samtiden.

\section{Bidrag til drøftingen av hvilke tolkningsfellesskap som gir begrepet kunstnerisk kvalitet innhold}

I en kritisk granskning av denne studiens troverdighet lener jeg meg mot noen spørsmål som Fejes og Thornberg (2010, s. 65) anbefaler for å drøfte kvalitet i en studie.

Denne artikkelen er den første i en serie av studier innenfor et forskningsprosjekt som undersøker kvalitetsforståelser i de ulike fagplanene i kulturskolens rammeplan «Mangfold og fordypning». Jeg har forsøkt å gjøre funnene valide gjennom drøftinger med sentrale personer i Norsk kulturskoleråd. I arbeidet med denne studien var idéen fra begynnelsen å gjøre en sammenlikning med finsk grunnundervisning i kunst innenfor teater. I arbeidet ble det imidlertid nødvendig å stoppe opp og ta et nytt grep fordi nytt læreplangrunnlag er under utvikling i Finland. Denne studien kunne kun omfatte et sammenliknende materiale knyttet til innledende skisser av de generelle delene i finsk rammeplanarbeid. Sammenlikningen er dermed ganske provisorisk, og det sammenliknende materialet er under utvikling. Allikevel tilbyr sammenstilling av disse skissene et litt fremmedgjørende blikk på hvordan det finske tolkningsfellesskapet kan bidra til bevisstgjøring av det norske tolkningsfellesskapet (som rammeplanen riktignok kaller et uenighetsfellesskap). Den norske rammeplanen 
er et ferdig designet produkt og viser dermed den enighet som et samlet kulturskolefelt har landet på.

Mine funn i studien kan være begripelige for dem som hører til denne konteksten, og funnene kan bidra til en dypere forståelse av praksisen i kulturskolens hverdag. Analysene kan bidra til en bevisstgjøring om at begrepet kunstnerisk kvalitet må defineres for å kunne bli til nytte for det arbeidet som gjøres i en kulturskolekontekst. Et alternativ er å ta i bruk noen andre begreper som peker på hva som gir mening og hva som er kunstens måte å produsere kunnskap på.

\section{Referanser}

Bolander, E. \& Fejes, A. (2015). Diskursanalys. I A. Fejes \& R. Thornberg (Red.), Handbok $i$ kvalitativ analys (s. 90-114). (Andra upplagan). Stockholm: Liber.

Bourdieu, P. (1972). Outline of a theory of practice. Cambridge: University Press. (Først utgitt på fransk)

Bourdieu, P. (1979). Distinction: A social critique of the judgement of taste. London: Routledge. (Først utgitt på fransk)

Eliassen, K.O. (2016). Innledning. I K. Eliassen \& Ø. Prytz (Red.), Kvalitetsforståelser. Kvalitetsbegrepet $i$ samtidens kunst og kultur (s. 7-23). Oslo: Kulturrådet.

Eliassen, K.O. \& Prytz, Ø. (Red.) (2016). Kvalitetsforståelser. Kvalitetsbegrepet i samtidens kunst og kultur. Oslo: Kulturrådet.

Fairclough, N. (1995). Critical discourse analysis: the critical study of language. Harlow: Pearson education.

Fish, S.E. (1976). Interpreting the "Variorum". Critical Inquiry, Vol. 2, No. 3. (Spring, 1976), 465-485.

Foucault, M. (1999). Diskursens orden. Oslo: Spartacus (først utgitt på fransk; overs. Espen Schanning).

Goodlad, J. and associates (1979). Curriculum inquiry. The study of curriculum practice. New York: MacGraw-Hill.

Meyer, S. (2010). Visuell makt Bilder, blikk og betrakter. Oslo: Universitetsforlaget.

McMullen, L. (2011). A discursive analysis of Teresa's protocol. I F. Wertz, K. Charmaz, L.M. McMullen, R. Josselson, R. Anderson, \& E. E. McSpadden, Five Ways of doing qualitative analysis (s. 205-223). New York: The Guilford Press.

Kauppinen, E. \& Hartikainen, M. (2016). Läroplansgrunderna för grundundervisning i konst. Beredning av de allmänna delarna. Granskning av de inledande skisserna [forf. overs. til svensk av ppt-presentasjon ved Utbildningsstyrelsens seminar 15.4.2016 om reformering av læreplansgrunder som skal tas $\mathrm{i}$ bruk 2018. http://www.oph.fi/download/176459_TPO2018_seminaari_Yleisten_osien_valmistelu_15.4.2016.pdf. Lest 1.9.2016.

KL06 (2006). Lareplan for kunnskapsløftet. Oslo: Kunnskapsdepartementet.

Lindsköld, L. (2016). Ett användbart kvalitetsbegrepp: kvalitetsbedömning i litteraturpolitiken. I K. Eliassen \& Ø. Prytz (Red.), Kvalitetsforståelser. Kvalitetsbegrepet $i$ samtidens kunst og kultur (s. 162-182). Oslo: Kulturrådet.

Maurseth, A.B. (2015). Det sanselige potensialet. Kunst, estetikk og politikk med utgangspunkt i to bøker av Rancière. Kunst og kultur $\mathrm{Nr} 3 / 2015$. s. 177-183.

Meld. St. 28 (2015-2016). Fag - Fordypning - Forståelse - En fornyelse av Kunnskapsløftet. https://www. regjeringen.no/no/dokumenter/ meld.-st.-28-20152016/id2483955/. Lest 18.10.2016.

Moss, P. (2016). Why cant't we get beyond quality? Contemporary Issues in Early Childhood. Vol. 17 (1), 8-15.

Norsk Kulturskoleråd (2016). Rammeplan for kulturskolen. Mangfold og fordypning. Oslo: Norsk Kulturskoleråd.

Norsk Kulturskoleråd (2003). Rammeplan for kulturskolen. På vei mot mangfold. Oslo: Norsk Kulturskoleråd.

NOU (2015). Fremtidens skole. Fornyelse av fag og kompetanser. Norges offentlige utredninger 8:2015. Oslo, Norway: Kunnskapsdepartementet.

Oterholm, K. (2016). Folkebibliotek og kvaliteter i litteraturen: et formidlingsperspektiv. I K. Eliassen \& Ø. Prytz (Red.), Kvalitetsforståelser. Kvalitetsbegrepet $i$ samtidens kunst og kultur (s. 140-161). Oslo: Kulturrådet.

Ranciére, J. (2013). Aisthesis. Scenes from the aesthetic regime of art. New York: Verso. Først utgitt på fransk 2011.

Rancière, J. (2012a) Den emansiperte tilskuer. Oslo: Pax. Serien Artes. Først utgitt på fransk 2008. Oversatt av Geir Uvsløkk.

Rancière, J. (2012b). Sanselighetens politikk. Oslo: Cappelens upopulære. Først utgitt på fransk 2000. Oversatt av Anne Beate Maurseth. 


\section{A.-L. Østern}

Smith, P. \& Riley, A. (2009). Cultural theory an introduction (andre utgaven.). (første utgave 2001). Malden, MA: Blackwell.

TPO- liitto [Forbundet for grundundervisning i konst] http://www.artsedu.fi/fi/etusivu. Lest 15.9.2016.

Undervisnings- och kulturministeriet (2011). Statsrådets redogörelse om kulturens framtid. Publikation 2011:8. Helsingfors: Undervisnings- och kulturministeriet. Kultur-, idrotts- och ungdomspolitiska avdelningen. http://www.minedu.fi/export/sites/default/OPM/Julkaisut/ 2011/liitteet/OKM08.pdf?lang=fi

Utbildningsstyrelsen (2003). Fördjupad lärokurs i teaterkonst i grunderna för läroplanen för den grundläggande konstundervisningen 2002. Föreskrift 40/011/2002. Helsingfors: Utbildningsstyrelsen.

Utbildningsstyrelsen (2005). Grunderna för läroplanen för den grundläggande konstundervisningen, allmän lärokurs 2005. Föreskrift 11/011/2005. Helsingfors: Utbildningsstyrelsen.

Østern, A.-L. (Red.) (2014). Dramaturgi i didaktisk kontekst. Trondheim: Akademika.

Østern, A.-L., Stavik-Karlsen, G. \& Angelo, E. (Red.) (2013). Kunstpedagogikk og kunnskapsutvikling. Oslo: Universitetsforlaget.

Østern, A.-L. (Red.) (1994). Evaluering i modersmålet - nordiskt perspektiv. Publikation nr 13 Vasa: Pedagogiska fakulteten vid Åbo Akademi.

Østern, A.-L. (Red.) (1997). Unga röster. Om undervisning $i$ modersmål och litteratur $i$ finlandssvenska högstadier och gymnasier. SMLF Årsskrift 1997-98. Publikation nr. 25. Vasa: Pedagogiska fakulteten vid Åbo Akademi.

Østern A.-L., Risan, L., Strandberg, M. \& Eriksson, S.A. (Red.) (2005). Drama, dramaturgi och kulturell läsfärdighet. SMLF:s årsskrift 2005. Publikation nr 10. Vasa: Pedagogiska fakulteten vid Åbo Akademi.

Østern, T.P. (Red.) (2016). Cutting edge kulturskole! -Forskning, fag og praksiser $i$ manesjen 27.-28.10. 2015. Konferanserapport. Nettverk for kulturskolerelatert forskning. Trondheim: Norsk kulturskoleråd. Nedlastes fra http://www.kulturskoleradet.no

\section{Relevante internetadresser}

Norsk nettverk for kulturskolerelatert forskning http:/www.kulturskoleradet.no/

Utbildningsstyrelsens Grunder för den grundläggande utbildningen 2014. http://www.oph.fi/lagar_och_ anvisningar/laroplansoch_examensgrunder/grundlaggande_utbildningen

Utbildningsstyrelsens informasjon om arbeidet med ny rammeplan for finsk grundundervisning i konst. www. oph.fi/GRK2018 